\title{
1
}

\section{Class, sexuality and home in interwar London}

\section{Elizabeth Darling}

$I^{n}$ February 1932, the young architect Acheson Best Overend (1909-77) wrote from London to his family in Melbourne, describing the latest project on which his skills as a draughtsman were deployed while he worked in the office of Wells Coates (1895-1958). Australian tongue firmly in his cheek, he reported: 'We are in the throes of designing the interiors of a love nest for one of the Socialist members in Parliament ... just the bare 2500 pounds on three rooms' (Overend 1932). He was referring to the transformation of the ground and first floor of the substantial mansion overlooking Hyde Park owned by the MP, George Russell Strauss (1901-93), to which he would bring his new bride, Patricia O'Flynn (d.1987), following their marriage in March 1932. The substitution of some of the house's elaborate late nineteenth-century interiors with Coates's calm Modernist idiom served to symbolise both the advent of its new incumbents and, more generally, the order of things that both client and architect envisaged for the modern world.

The idea of a home as a 'love nest, and the requirement of a particular and novel setting to this end, establish the core themes of this chapter, which explores how ideas about marriage, sex and sexuality were rehearsed in architectural form in the interwar decades. This was a period when the transition from the idea of marriage as a pragmatic union to one founded on romantic love, which had emerged as part of bourgeois ideology during the nineteenth century, was both refined and began to become more widespread. The result was a model of marital relationships that has remained largely 

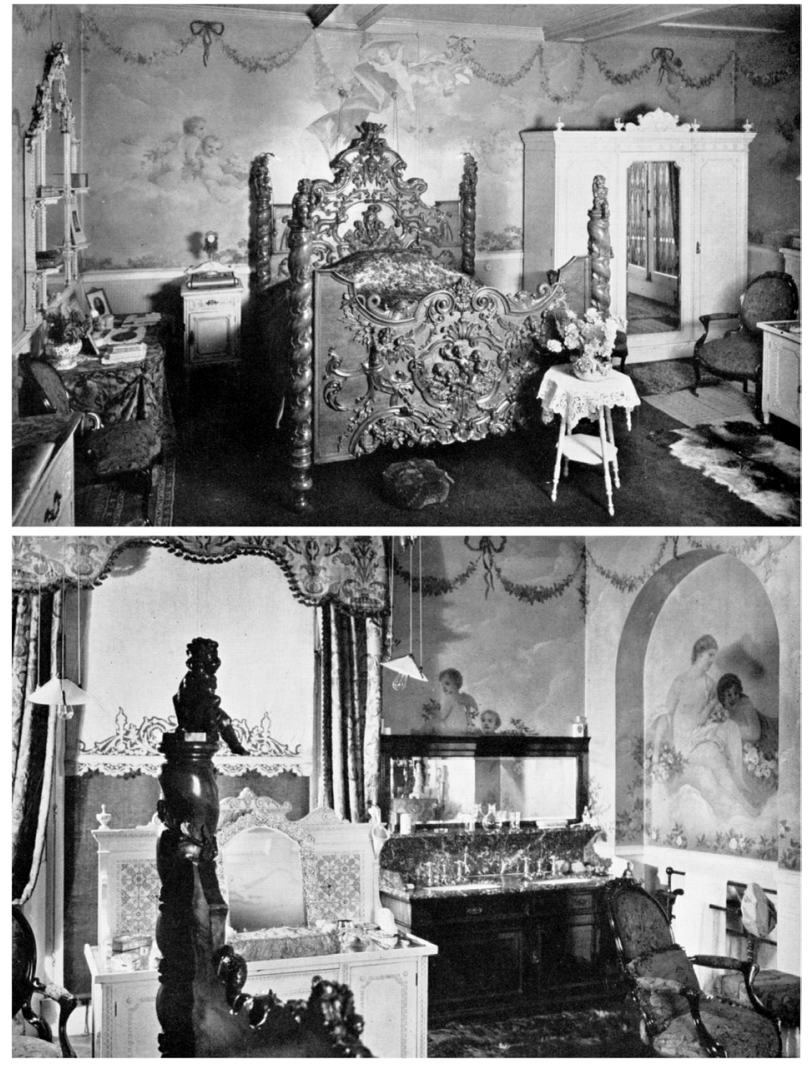

FIGURE 1.1 Two views of the principal bedroom of 1 Kensington Palace Gardens before its refurbishment by Wells Coates for George Russell Strauss, 1890s (destroyed).

dominant until the recent present (Gillis 1995: 148-50). The social historian Judy Giles summarises the interwar shift neatly, speaking of 'new forms of conjugal heterosexuality not necessarily linked to procreation' (Giles 1995: 97). This reflected the general impulse in modernity for 'emotional and social betterment' as well as a desire for material enhancement (Giles 2004: 62). The former also inaugurated a concomitant ordering of other forms of sexuality - free, same-sex, commercialised - as 'dangerous' (Giles 1995: 122) at the same time as it signalled a recognition (and de facto legitimation, perhaps) of practices which, especially in the case of homosexual love, were becoming forms of identity as we know them now.

That these concepts were shifting rather than settled, contested rather than consensual and nuanced by class and sexuality is reflected in the choice of examples discussed here. Two were new interiors in existing buildings: the 'love nest,' 1 Kensington Palace Gardens, completed in Spring 1932; the other, the upper floors of 34 Gordon Square, completed towards the end of 1934 by 


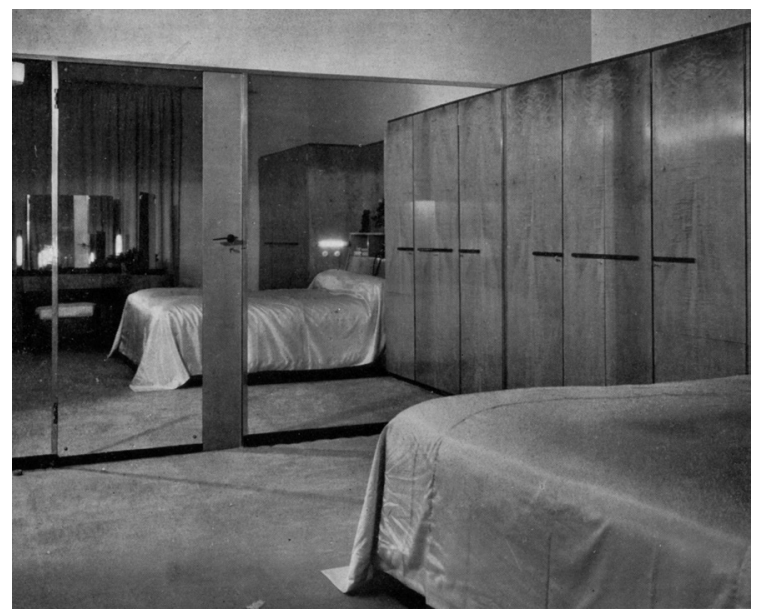

$A Q$ : Please check and confirm the fixed running head is ok.

FIGURE 1.2 The principal bedroom at 1 Kensington Palace Gardens, as redesigned by Wells Coates, 1932 (destroyed). Courtesy of the Cohn Family.

Wells Coates for the actors Elsa Lanchester (1902-86) and Charles Laughton (1899-1962). The third is Kensal House, Ladbroke Grove, a purpose-built block of social housing designed by a team led by Elizabeth Denby (1894-1965) and Maxwell Fry (1899-1987) for the Capitol Housing Association (a subsidiary of the Gas, Light and Coke Company), which was opened in late 1936. All are in London, and all took the vanguard forms of Modernism in their design. Each was featured extensively across a range of media - though 34 Gordon Square less so - with some emphasis placed on images of their bedrooms. Each embodies particular aspects of the shifts outlined above, while the combination of metropolitan location, architectural language and their mediation suggests that they were intended by their clients, architects and journalists (or some admixture thereof) as models to be disseminated from the nation's centre.

\section{Kensington Palace Gardens}

Following their wedding, Strauss and his new bride, O'Flynn, took up residence at 1, Kensington Palace Gardens (1KPG). This had been Strauss's family home. He had inherited the substantial Italianate mansion, and a considerable fortune, from his metal merchant father who had died in 1920. He was also heir to the house's interiors: elaborate confections of painted walls and decoratively carved furniture, commissioned at the time of his parents' marriage in the 1890s. Strauss spent approximately $£ 150,000$ in today's values (Offer and Williamson 2015) on the transformation of the main public spaces on the ground floor of the house (entrance hall, hall, new dining and living 
room, ballroom), a modernised kitchen in the basement, and upstairs, a new principal bedroom with anteroom, boudoir, dressing room and a refurbished bathroom nearby. The rest of the house was left unchanged (Strauss Family 2009).

The dismantling of the parental home and its marked transformation by a son for his bride make for a very obvious symbolism of the supplanting of one generation by the next. But to contemporaries, a further symbolism might also have registered: the interior as a statement of an eminently modern marriage. The configuration of space in this 'love nest,' in Overend's perceptive phrase, and in particular the glamour and nature of the bedroom and its fittings, was a clear statement of (a declaration of faith in) the new paradigm of bourgeois marriage. For the idea of the companionate marriage, in which a woman and man were seen as equal partners and sex a vital expression of their union, was a concept promulgated by and (largely) for the middle classes (Giles 1995: 97).

In what Hilary Hinds so evocatively calls the new 'marital economy,' certain themes were foregrounded (Hinds 2010: 294). Fostered by the writings of pre-war sexologists, these themes stressed women's right to sexual pleasure, while after 1918, campaigners such as Marie Stopes argued that the married woman's role was as much sexual as it was maternal and it was understood that 'sexual expression by both sexes (within marriage) was essential to, if not the core of, a sense of self-identity' (Holtzman 1982: 42-3; Giles 1995: 123). Crucial here was the growing access for middle-class women to birth control, which allowed family size (and the fear of endless childbearing) and thus maternal responsibility to diminish. A corollary of this was the concept of woman's 'sexual authority', which enabled her to expect her husband to give her pleasure as well as respect her desire (or otherwise) for sex (Holtzman 1982: 45). Thus, a modern middle-class woman might be expected to cultivate her attractiveness as hostess, mother and sexual partner. As the wife of an $\mathrm{MP}$, the reconfigured ground floor spaces of $1 \mathrm{KPG}$ certainly provided a setting in which O'Flynn could perform the first role; the modernity of their design connoting, as noted above, the progressiveness of the couple's selves and their politics (Strauss stood to the far left of the Labour Party, O'Flynn was a committed Labour Party member and much interested in issues of workingclass poverty and of birth control). The vital complement to this, however, was the reordered environment of the spaces upstairs.

Coates's redesign created a series of spaces that, at the same time as they enabled the Strausses to assume their public roles of politician and wife, provided the setting in which they could perform their private roles as life partners. Thus, the bedroom was complemented by a dressing room and a boudoir for O'Flynn and an anteroom for Strauss. The boudoir, furnished with writing desk and chair, easy chair and bookshelves, was the space in which O'Flynn curated the couple's social calendar. The dressing room, with power 


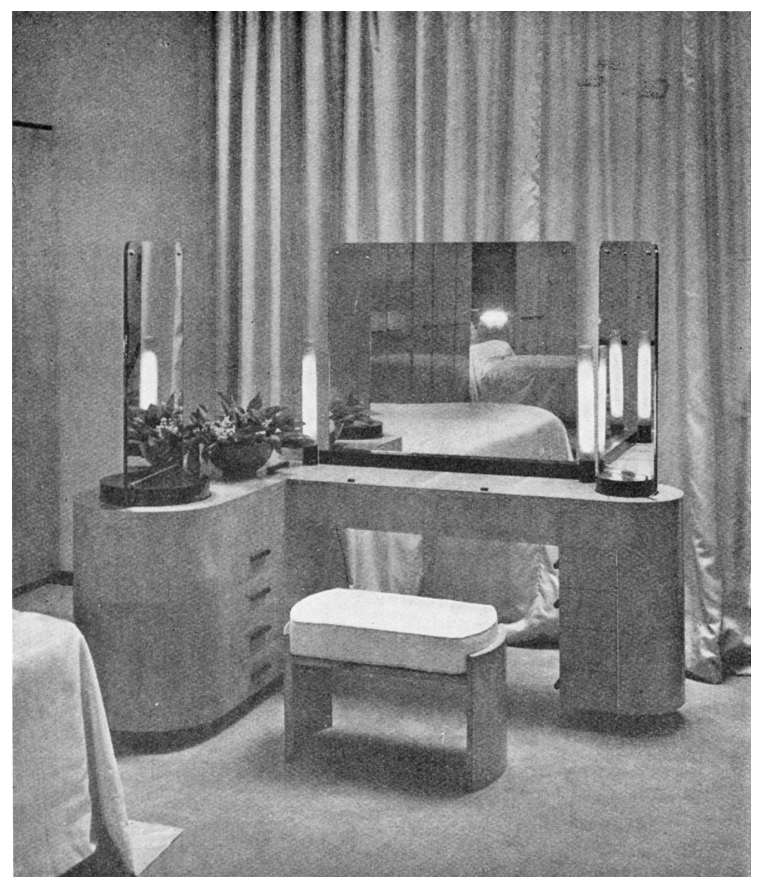

FIGURE 1.3 The dressing table in the bedroom at 1 Kensington Palace Gardens, 1932 (destroyed). Courtesy of the Cohn Family.

points for an electric iron and a sewing machine and with a large mirror, was the site where the appropriate outfit for the day or evening event could be prepared and donned. The anteroom served this function for her husband (Coates 1932b).

Linking the public and private sides of the marriage was the dressing table in the bedroom. A custom-made and substantial piece of furniture, Coates designed it so that all the paraphernalia of make-up was easily to hand: each drawer was pivoted to turn out, presenting products as though in a shop display (Coates 1932b). The main feature was, however, the arrangement of the mirrors. To either side of the main glass stood separate glasses, tinted blue on one side and peach on the other. The former colour, Overend reported, showed up the flaws that needed correction with make-up and powder (Overend 1935). ${ }^{1}$ Once done, at the turn of a mechanism, the mirrors reversed so that O'Flynn could see her final appearance in the more flattering pinkish light (a tint also used in the dressing room mirror). At this machine for beautification, then, O'Flynn could complete her toilette before making her descent to the public rooms on the ground floor or prepare herself for bed.

As the most intimate part of the 'love nest,' the bedroom was at the core of Coates's design and we might read the sumptuousness of its fittings and 
fabrics as a celebration of that intimacy (Figure 1.2). This began with the carpet, which, as Overend wrote, 'gives a warm softness and quietness which form the most pleasing features of the modern adult bedroom.' Next came the mirrored wall. This, the Australian noted impishly, at the same time as it gave a greater suggestion of space, 'also affords quite a deal of interest and amusement when fooling about going to bed and getting up on bright and cheerful mornings. The effect might be salutary also for people just letting themselves run to seed' (a reminder that the form of the body became increasingly important in the new sexual regime).

Above all, it was the beds that formed the centrepiece of the room. In that new 'marital economy of sexual intimacy', the choice of twin beds to furnish the middle-class principal bedroom in place of the Victorian double bed was key. They symbolized that the couple were a pair of separable equals and functioned as a powerful negotiating tool for the woman partner (Hinds 2010: 294). Unlike in a double bed, in which intimacy might be said to be forced, the twin beds (thanks to castors) could be pushed together (as they are in Figure 1.2, though note the distinct pillows, compared with the bolster of the 1890s bed, and the counterpane that covers the divide between the two beds) for a wanted intimacy, or kept apart when sexual intimacy was not welcome. Thus, spatially, the beds were far more dominant than in the 1890s interior. They stood proud in the room, framed by fitted wardrobes, and were reflected in the glazed wall and dressing table mirrors. The silky chartreuse green counterpane further delineated them from the muted colours of the carpet (beige) and the fittings (grey-stained sycamore veneer).

In this 'mise-en-scene for the "married couple"', Strauss and O'Flynn conformed to contemporary expectations of what (upper) middle-class marriage should be (Hinds 2010: 294) and, with their architect, offered a particularly sophisticated and future-oriented image of its form. As such, it and the rest of the 'love nest' were widely mediated. Just a few months after its completion, Coates included a considerable number of the before and after images of the interiors in his major article for the Architectural Review 'Furniture Today Furniture Tomorrow - Leaves from a Meta-technical Notebook' (Coates 1932a), listing with glee the contents of the 1890s bedroom ('kidney shaped dressing table with silk brocade drapery, two ornamental jardinières, a paper cylinder and brown parquet linoleum'). The contrasting images became commonplace in 1930s design literature and may be found, for example, in the pamphlet that accompanied a series on design produced by the BBC in April 1933 (Carrington 1933). Later, and indicative of the dissemination of these ideas beyond the highbrow realms of the national programme, they were featured in Interior Decorating, number 13 of The Studio Publication's 'How to' series (Miller 1937: 70-4). The spread of such ideals beyond the middle 
classes is a theme to which this chapter will return. In the meantime, attention turns to an interior that was again designed by Coates but that offered a rather different representation of the forms of marriage in the interwar decades.

\section{Gordon Square}

Strauss and O'Flynn had met their architect, Coates, through a friendship network that was distinctly bohemian (Darling 2007: 34-6) and included his clients for 34 Gordon Square (34GS), Elsa Lanchester and Charles Laughton. In contrast to the Strausses, however, the actors' relationship was less straightforward: the outcome of a complex negotiation that accommodated an older and more pragmatic view of marriage with the more 'dangerous' forms of sexuality outlined above.

The pair had met in 1927 when both appeared in the play Mr Prohack. She was a dancer and actress who had lived independently since her early teens and who had run a bohemian nightclub, the Cave of Harmony (which also served as her home). Her familiarity with the unconventional is reflected in a performance she choreographed using one of the sexologist Krafft-Ebbings's case studies as its theme (Lanchester 1983: 70). Before meeting Laughton, she had enjoyed a series of affairs and undergone at least one abortion (the actress Tallulah Bankhead advising her on whom to consult). The possibility of a new phase of her career, marked by a performance in the West End, and a growing weariness of her own independence is indicated by Lanchester's recollection of what brought the pair together: 'We found in each other a mutual friendship that we both needed badly - Charles because he felt lonely and was called ugly, and I because I was too "bohemian", with too many odd friends who stayed up half the night' (Lanchester 1983: 83). Although outwardly Laughton was far more conventional - the son of Yorkshire hoteliers, his mother a devout Roman Catholic - it was this bond of 'mutual oddity' that enabled them to overcome the obstacles that the evolution of contemporary sexualities put in their way (Callow 1987: 277).

Initially, all seems to have flourished between them and the couple moved in together. By early 1929, however, they felt an increasing tension between their 'free love' union (which echoed that of Lanchester's parents, who had never married) and their reputation, as their careers - Laughton's especially - brought them more into the public eye. She recalled: 'Charles and I were too shy to remain unmarried. To go on living together was just too embarrassing for us to cope with. Certainly, it would have acted as a brake to Charles's growing career and also hurt his northern hotelier family and his Catholic mother' (Lanchester 1983: 90). Regardless of their particular 
desires, the 'dangerous' had to be put aside in order to secure their longterm future. Their marriage was the first step in the formation of what a biographer has called 'Charles Laughton inc ... a kind of corporation ... with very few shareholders outside the two of them' whose primary function was to promote him and his work by any means necessary (Singer 1954: 53).

The aura of respectability and normality that marriage bestowed (for good measure, it was announced in The Tatler) became even more important when, in spring 1930, Laughton revealed to Lanchester that he was gay. This followed an incident in which a rent boy, seeking to extort money from him, was arrested outside their front door for suspicious behaviour; Laughton was subsequently called as a witness at the trial (although his name was kept out of the papers). Notwithstanding Lanchester's many friends in London's gay community (John Banting, Cedric Morris, Arthur Lett-Haines, Robert Medley and Rupert Doone, inter alia), and reflecting her husband's skill at concealing his inclinations (the 'loneliness' to which she responded was perhaps this), the news came as a complete shock. Once she had rallied, however, the promotion of 'Charles Laughton Inc.' returned as her priority.

In a climate in which the codification of homosexuality as dangerous was leading to a growing number of prosecutions (as Laughton's experience demonstrated), she knew that if the news of his dangerous sexuality got out, 'it would have ruined him' (Sigal 1983: 8). It thus became even more important to project their image as the happily married couple of contemporary middleclass convention. The contrast between public and private faces meant that their marriage evolved in effect into a pragmatic relationship in which romantic love was decoupled from the conjugal, one more reminiscent of the forms of marriage which the nineteenth century had begun to displace. This status allowed, as the historian John Gillis notes, the marital state to continue unthreatened by homosexual or other affairs (Gillis 1995: 148). Although according to Lanchester, the couple hardly discussed what had happened, not least because she felt 'he was not capable of that' (being too closeted), there was one significant material outcome, one which demonstrates how symbolic furniture can be (Sigal 1983: 8). When Laughton confessed that he had had the boy on their sofa, Lanchester insisted they got rid of it (Lanchester 1983: 90).

It was in this context that Lanchester commissioned Coates to design a home for the pair. The development of Laughton's career had seen him travel frequently between Hollywood and London since their wedding, and it was not until he committed to performing in the 1933-4 season at the Old Vic that the couple considered themselves able to settle permanently. Lanchester spent much of the autumn of 1933 searching for a suitable home, eventually settling on the upper three floors of a house in Bloomsbury's Gordon Square.

In some respects, the commission had much in common with $1 \mathrm{KPG}$. In both instances, Coates grappled with an over-decorated set of nineteenth- 
century interiors. Lanchester reported that 'The sitting room was done in "Victorian Chinese": a sort of egg-yellow ensemble and a wealth of teacaddies' (Lanchester 1938: 134). Coates deployed the same vocabulary of sliding screens, muted colour palette and built-in furniture to replace such décor. And while both were designed as marital homes, here the similarity ended. Whereas at $1 \mathrm{KPG}$, public and private spaces were complements in the formation of the Strausses' companionate marriage, at 34GS they were competing narratives. It was to be no 'love nest,' but the headquarters of 'Charles Laughton Inc.'

As such, the public spaces, all on the first floor, were designed to create a setting for the pair to enact their coupledom. The principal space was a combined living and dining room that was divided by sliding screen doors to be opened or closed, depending on how the couple were entertaining. This they did a good deal, working hard to convey that they were a loving and intimate couple. A contemporary recalled, 'They never left each other alone in public. They were always mauling each other.' She added, perceptively, that she assumed therefore that they 'were not very sexually involved' (Benita Armstrong in Callow 1987: 277). These were discrete performances, then, as time-limited as a play, and visitors were generally discouraged from staying the night.

The first floor was the business floor. Visitors were to remain at this level, their exposure to the couple carefully controlled. Upstairs was different, the place for the realities and practicalities of their relationship. The out-ofstep pragmatism of their marriage was signalled by the fact that they had separate bedrooms, each designed to reflect their personal tastes and needs. Lanchester's simply had a bed - its striped bed linen matching the curtains made from gentleman's shirting material - wardrobe, dressing table and easy chair. Laughton's was a shrine to himself and contained a sunlamp above the bed, some of his art collection on the wall as well as a bedside cabinet for the china he collected from street markets and junk shops. Coates was also reported to have designed him a small gymnasium (Meynell 1971: 217-18), though whether this was within the bedroom is unclear. If there were conjugal relationships to be enjoyed at home (and romantic interludes with others outside the home were surely more the norm for both), it was perhaps Lanchester who allowed Laughton into her room - a rare moment of identification with more up-to-date forms of female sexuality.

Whatever the relationship embodied in the actors' bedrooms, in the public mind Lanchester worked hard to project the more modern image of the couple as heterosexual soulmates and good friends. She thereby contributed to the more general dissemination of the model of modern marriage echoed in contemporary women's magazines as well as contributing to the assimilation of film actors into the aspirational condition of what we would now call 'celebrity culture.' Lanchester exercised a firm control over this process, 
something reflected in the way she discussed their home. Laughton's filming commitments meant that, almost as soon as the interiors were finished, the couple left for Hollywood, and it was a few years before they worked in London again and took up residence. It was at this point that Lanchester used the interiors to promote their coupledom (presumably as publicity for current projects). In 1938, her book Charles Laughton and I was published. A wife's account of her more famous husband, the creation of their home took up several pages (Lanchester 1938: 134-5 and 189-201). She presents the flat as a setting for their marital life and an exercise in Laughton's taste as both

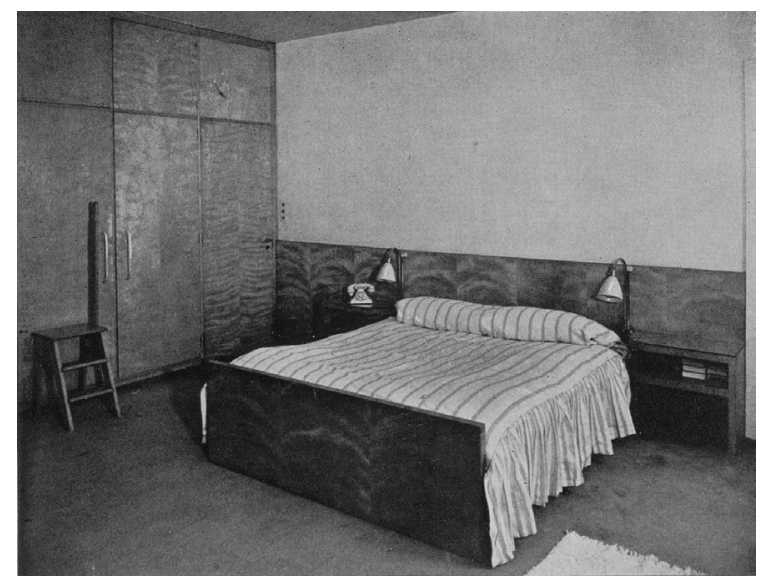

FIGURE 1.4 Elsa Lanchester's bedroom at 34 Gordon Square, by Wells Coates, 1934 (destroyed). (C) The British Library Board, LOU.LON 571 [1938].

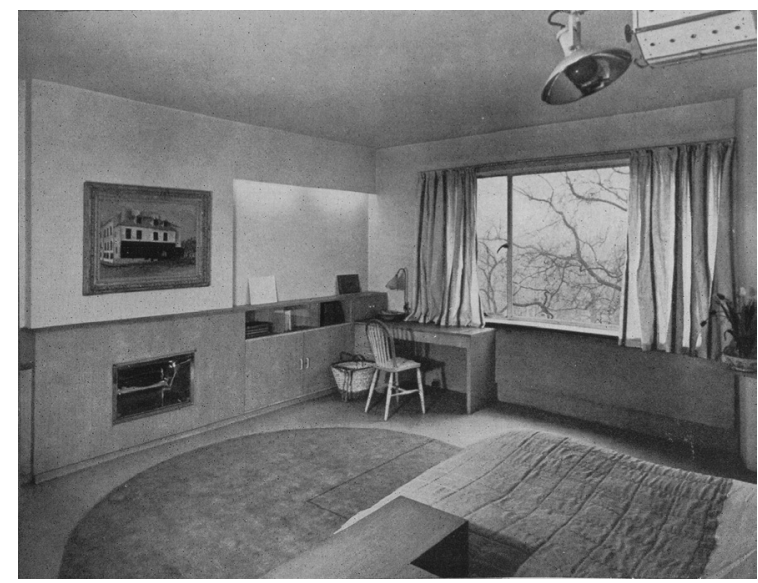

FIGURE 1.5 Charles Laughton's bedroom at 34 Gordon Square, by Wells Coates, 1934 (destroyed). (C) The British Library Board, LOU.LON 571 [1938]. 
client and collector of art and ceramics, writing how she derived 'pleasure out of being married to a successful magpie' (Lanchester 1938: 196). In this book, the bedrooms were not featured, the images focusing on the public spaces and including several of Lanchester looking adoringly at Laughton.

That same year, presumably as promotion for the book (as well as their public image), the interiors were featured in an article for the magazine Woman's Journal entitled 'Background for Talent' (Woollcombe 1938: 52-5). That their talent was to persuade the public about the happiness and authenticity of their marriage bypassed the journalist. She was content to offer a rather bland description of the interiors with no comments on the particular nature of the furnishings (including the bedrooms; their only published depiction). Her focus instead was on the materials used and the décor as a whole, along similar lines to the 'How to' book in which the 1KPG interiors had appeared. Likely under Lanchester's direction, the text also emphasised Laughton's career and presents her (despite the fact she continued to act) very much as wife and helpmate, an image reinforced by a photograph of the couple sitting together reading a book.

While both $1 \mathrm{KPG}$ and 34GS were interiors for elite couples within the middle class, each, in its own way, conformed to the increasingly dominant notion of what more widely constituted a modern marriage within that class. We have also seen how their mediation both reinforced and disseminated this model beyond that class. How an environment might be physically configured to spread the new paradigm is the subject of the final section of this chapter.

\section{Kensal House}

If, as Judy Giles noted, the majority of the middle classes benefitted from the possibilities for material, social and emotional betterment that modernity offered in the interwar decades, the same could not be said for the men and women of the nation's working classes. For some, material conditions did improve under the post-war housing acts and, from the mid-1930s, the inauguration of a more thoroughgoing slum clearance programme. At the same time, maternal and child welfare provision increased and the upper echelons of the working classes (especially those in areas where new industries predominated, such as the South East and Midlands) could contemplate home ownership and through it access to the emerging consumer society, although most workers could be said to have been prevented from experiencing progress fully. Certainly, this was the perception of many social reformers and enlightened local councils throughout the period, but their attempts to bring workers into modernity were often circumscribed by a focus solely on material 
betterment and concomitantly, as Giles notes, by particular ideas of the role of women within working-class marriage (Giles 1995: 124). So while feminist campaigners like Stopes 'ostensibly believed' that all women should enjoy the emotional betterment represented by 'meaningful sexual relationships,' Giles argues that a class bias that conceived of working-class women first and foremost as housewives and mothers caused them to focus on the provision of advice and reform measures in these areas (Giles 1995: 124). There were, however, some reformers who moved beyond this bias and for whom emotional emancipation was understood as an absolutely integral part of working women's progress. Kensal House was perhaps the most emphatic statement of such ideas, evidenced in the form and planning of the scheme and the social programme that accompanied it.

Kensal House had always been intended as a model environment. It originated in a 1933 proposal by the Gas, Light and Coke Company's directors to build a block of workers' flats that would demonstrate the cheapness and efficiency of its fuels and equipment at a time when central government was legislating for slum clearance. For its design, the Company drew on the expertise of a committee of architects that it retained, with Maxwell Fry taking the lead. They also appointed the housing consultant Elizabeth Denby to advise them, one of the earliest commissions of her career (Darling 2005b: passim). Under her direction, the scheme became much more than a means to promote gas. She had developed a housing theory that stressed the interconnectedness of material and social improvements in new working-class housing and placed great emphasis on the improvement of women's lives, not just as housewives and mothers but as individuals (in and of themselves) and as partners with their husbands in a modern companionate marriage. Only in this way could women become fully present in modernity.

Every aspect of the scheme was designed to this end. Befitting her and Fry's Modernism, the maximum of technologies was used to construct well-built flats, planned on labour-saving lines and equipped with the most up-to-date gas equipment. Material needs met, the tenants' social lives were catered for through the provision of clubrooms (one for the adults and one for the children), the institution of a tenants' committee to run the estate on a daily basis, allotments and a playground for the children. An on-site nursery school was also provided for which all preschool residents were eligible. Denby intended that the resulting free time should be used for the mother's self-improvement and leisure rather than endless housework (already less likely given the efficiency of the design) if she did not work outside the home (Darling 2005a).

Amenities like the social clubs did not just enable a sense of community to develop across the estate, they also formed part of a range of devices to facilitate the evolution of the parents' relationship into a modern form, something prevented in the overcrowded slums from which most residents 


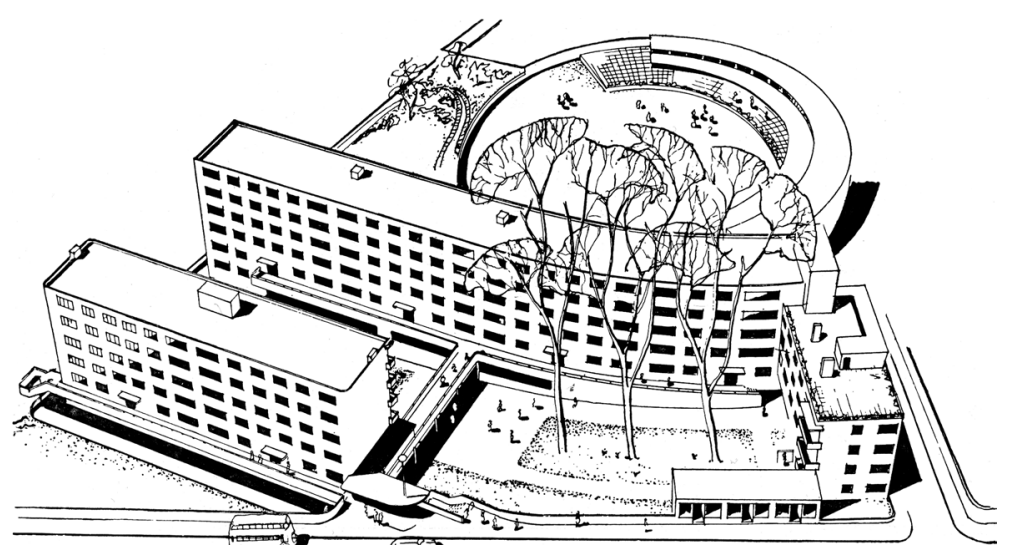

FIGURE 1.6 Kensal House, Ladbroke Grove, West London, perspective.

came. With the children entertained in their clubroom, mother and father could enjoy time together in the adult club at the end of the day. Their flat was also designed to enhance a sense of companionship. The majority of the 68 flats had three bedrooms, allowing parents, boys and girls to have their own bedroom. Moreover, as the plan shows, the children's rooms were accessed from the main hall. Once they had gone to bed, the living room door could be closed, creating a space entirely for the parents, for their bedroom opened off this space. For the first time, probably in their marital life, they had a space for and to themselves.

A contemporary image shows a bedroom furnished on model lines. Again, the choice of bed was meaningful. While the discourse of the companionate marriage permeated the scheme as a whole, a more complex symbolism was at play here. On a practical level, there was not room for twin beds but, in this context, the choice of a double bed served to reinforce the discreteness of the space. In the slum, at night the bed was a thing on which both parents and children would commonly sleep together and, if space was especially limited, during the day it might become a more general sitting surface. It was not a conjugal bed. Now enthroned in the centre of the Kensal House principal bedroom, its daytime emptiness hinted at pleasurable night-time activities at the same time as its doubleness connoted the pair (and only them) who would occupy it.

That Denby retained an affiliation to pro-maternalist politics is evident in the inclusion of the sling cot in the publicity photograph. She too believed that it was incumbent on the working-class woman to produce the children who would help Britain into the future, but that these should be wanted children whose upbringing was as good as possible. This explains the inclusion of a nursery school in the scheme, something highly unusual for the date. Even 


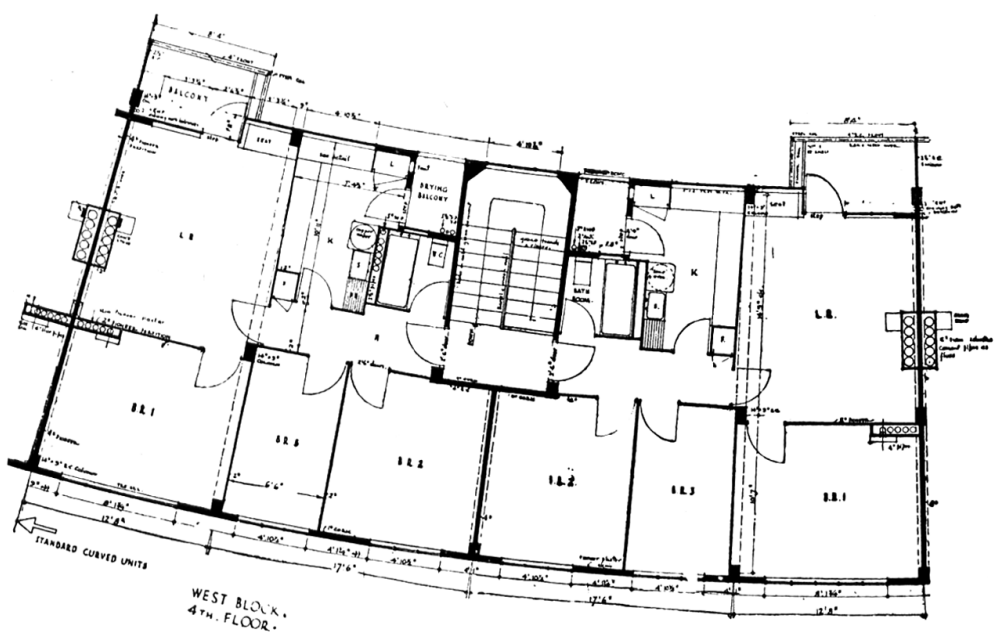

FIGURE 1.7 Plan of the main floors at Kensal House.

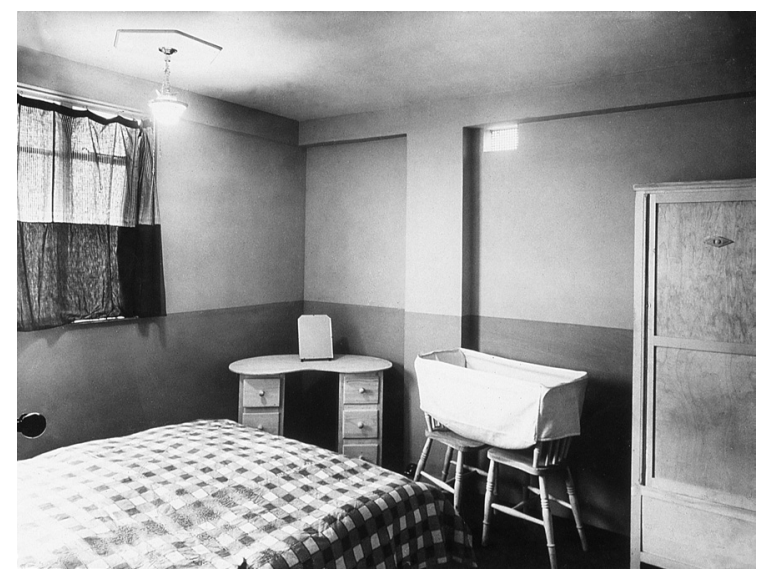

FIGURE 1.8 The principal bedroom, with model furnishing, of a Kensal House flat, 1937. RIBA Collections.

more remarkable is the fact that, in proximity to the flats, was a scheme whose proponents shared Denby's interest in working-class women land men) as sexual beings. This was the North Kensington Women's Welfare Centre, which had been opened in 1924 by a committee that included one of her closest friends (Leathard 1980: 31). Kensal House mothers were its direct constituents, being offered the birth control that had hitherto been more widely available to middle-class women and which could liberate them from endless childbearing. Both within and beyond Kensal House, therefore, the conditions were created in which working-class women could be modern 
wives, housewives and mothers. And as with the previous case studies, indeed all the more so, it was quickly harnessed into reformist narratives about the shape - both marital and architectural - of things to come, such as Marjory Spring Rice's 1939 social study Working Class Wives and, most visibly, as one of the schemes in the Army Bureau of Current Affairs poster series 'Your Britain - Fight for It Now' (Spring Rice 1939: 97/Moriarty 2003: 65-8). ${ }^{2}$

\section{Conclusion}

The rhetoric that surrounded the three examples discussed here formed part of the broader discourse that ensured that, after 1945, the conflation of romantic with conjugal love through the medium of the heterosexual marriage became the norm across the classes. By the end of the twentieth century, however, there were signs that this norm was faltering. As Gillis noted: 'Today ... everyone loves a wedding, and the high rates of divorce guarantee an inexhaustible supply for a culture that cannot get enough of perfect couples, even as it encounters ever greater difficulty in maintaining marriage itself' (Gillis 1997: 151). How these shifts, and new forms of legislated relationship such as civil partnerships and gay marriage, might come to be embodied architecturally in the first decades of the twenty-first century is for another historian to explore.

\section{Notes}

1 All quotations from this, until signalled otherwise.

2 These are too numerous to list (Darling 2007: 167-74 offers a survey).

\section{References}

Callow, S. (1987). Charles Laughton, a Difficult Actor. London: Methuen.

Carrington, N. (1933). Design in Modern Life (Broadcast Talks Pamphlet). London: The BBC.

Coates, W. (1932a). 'Furniture today furniture tomorrow - Leaves from a metatechnical notebook'. Architectural Review July: 29-34.

Coates, W. (1932b). 'Specification for One Kensington Palace Gardens'. Canadian Centre for Archives, Montreal, Canada, Wells Coates Papers, Box 4.

Darling, E. (2005a). 'A citizen as well as a housewife: New spaces of femininity in 1930s London'. In Negotiating Domesticity: Spatial Productions of Gender, edited by H. Heynen and G. Baydar, 49-64. London: Routledge. 
Darling, E. (2005b). "'The star in the profession she invented for herself": A brief biography of Elizabeth Denby: Housing Consultant'. Planning Perspectives 20 (July): 271-300.

Darling, E. (2007). Re-forming Britain: Narratives of Modernity before Reconstruction. London: Routledge.

Giles, J. (1995). Women, Identity and Private Life in Britain, 1900-1950. Basingstoke: Macmillan.

Gillis, J. (1997). A World of their Own Making. A History of Myth and Ritual in Family Life. Oxford: Oxford University Press.

Giles, J. (2004). The Parlour and the Suburb. Domestic Identities, Class, Feminity and Modernity. Oxford: Berg.

Hinds, H. (2010). 'Together and apart: Twin beds, domestic hygiene and modern marriage, 1890-1945'. Journal of Design History 23, no. 3: 275-304.

Holtzman, E. M. (1982). 'The pursuit of married love: Women's attitudes towards sexuality and marriage in Great Britain 1918-1939'. Journal of Social History 16, no. 2: 39-51.

Lanchester, E. (1938). Charles Laughton and I. London: Faber and Faber.

Lanchester E. (1983). Elsa Lanchester Herself. London: Michael Joseph Ltd.

Leathard, A. (1980). The Fight for Family Planning. London and Basingstoke: Macmillan.

Meynell, F. (1971). My Lives. London: Random House.

Miller, D. (1937). Interior Decorating. London and New York: The Studio Publications.

Moriarty, C. (2003). 'Abram Games: His work and its context'. In Abram Games, Graphic Designer. Maximum Meaning, Minimum Means, edited by C. Moriarty, J. Rose and N. Games, 38-120. Aldershot: Lund Humphries.

Offer, L. H. and S. H. Williamson (2015). 'Five ways to compute the relative value of a UK pound amount. 1270-Present'. Measuringworth.com.

Overend, A. B. (1932). Letter to family of 27 February, private collection.

Overend, A. B. (1935). 'The Bedroom'. Transcript of talk for $3 \mathrm{LO}$ radio, Melbourne, Australia, private collection.

Sigal, C. (1983). 'High life with Laughton'. The Guardian (10 September): 8.

Singer, K. (1954). The Charles Laughton Story. London: W. H. Allen.

Spring Rice, M. (1939). Working-Class Wives. Harmondsworth: Pelican.

Strauss Family. (2009). Interviews held June and July.

Woollcome, J. (1938). 'Background for talent'. Woman's Journal (October): 52-6. 